\title{
Effect of organic cow-dung based fertilizers on the soil microflora of fodder lands
}

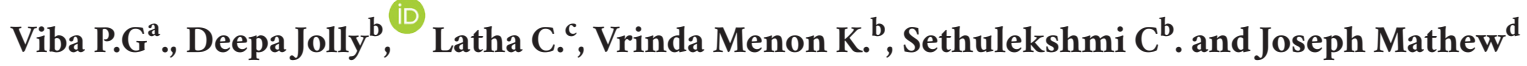 \\ ${ }^{a}$ Research Scholar, Department of Veterinary Public Health, College of Veterinary and Animal Sciences, Mannuthy, \\ Kerala Veterinary and Animal Sciences University, India \\ ${ }^{\mathrm{b}}$ Assistant Professor, Department of Veterinary Public Health, College of Veterinary and Animal Sciences, Mannuthy, \\ Kerala Veterinary and Animal Sciences University, India \\ 'Dean, College of Veterinary and Animal Sciences, Mannuthy, Kerala Veterinary and Animal Sciences University, India \\ 'Professor, Department of Livestock Production Management, College of Veterinary and Animal Sciences, Mannuthy, \\ Thrissur, Kerala, India
}

Corresponding author: Deepa Jolly | email: deepajolly@kvasu.ac.in

Co-authors: VPG: vibasunil1985@gmail.com ; LC: 1atha@kvasu.ac.in ;VMK: vrinda@kvasu.ac.in SC: sethulekshmi@kvasu.ac.in ; IA: josephm@kvasu.ac.in

Received: 15-08-2020, Accepted: 29-08-2020, Published online: 16-09-2020

\begin{abstract}
A study was pioneered to evaluate the effects of cow-dung based fertilizers on the culturable resident bacteria in the soil. The effect of organic cow dung based fertilizers namely cow dung, aerobic compost and vermicompost on the microbial population of the soil with respect to Bacillus and Pseudomonas, were observed in this study. Soil from fodder lands of the University Livestock Farm and Fodder Research Development Scheme, Mannuthy was treated with the fertilizers of cow dung- $1 \mathrm{~kg}$, aerobic compost- $200 \mathrm{~g}$, and vermicompost- $200 \mathrm{~g}$ to equally divided experimental field (total area $4 \mathrm{mx} 5 \mathrm{~m}$ ) and soil samples were analysed on the 0th, 10th, 21 st day after application. Overall results showed that mean Total Viable count ranged from $9.72 \pm 0.04$ to $10.38 \pm 0.19 \log _{10} \mathrm{CFU} / \mathrm{g}$, mean Bacillus count ranged from $6.15 \pm 0.027$ to $7.33 \pm 0.022 \log _{10} \mathrm{CFU} / \mathrm{g}$ and mean Pseudomonas count ranged from $5.95 \pm 0.33$ to $6.36 \pm 0.361 \log _{10} \mathrm{CFU} / \mathrm{g}$ from 0th to 21 st day. The application of cow-dung based fertilizers showed statistically significant increase in TVC and Pseudomonas count compared to control soil. Higher counts were observed on 21st day and lowest count on the 0th day. Of the three fertilizers, the aerobic compost fertilizer increased the Total Viable count, Bacillus count and Pseudomonas count compared to the other fertilizers. The highest Pseudomonas count was recorded in Vermicompost treated soil. Microbes in soil are affected by the physical and chemical constituents of the soil. Soil health in terms of the microbial load that enhances the fertility of soil is in many ways influenced by climate and the geography of the area. Thus, it could be surmised that organic farming could ensure inherent capacity to maintain and increase soil health and fertility leading to sustained increase in yield and production of crops, ultimately having a positive effect in improving the soil stability and economic sustainability in agriculture.
\end{abstract}

Keywords: Organic cow-dung based fertilizer, Soil microflora, Bacillus, Pseudomonas, Azetobacter spp

\footnotetext{
doi: https://doi.org/10.51128/jfas.2020.A004 How to cite this article: Viba P.G., Jolly, D., Latha C., Menon K. V., Sethulekshmi C. and Mathew J. 2020. Effect of organic cow-dung based fertilizers on the soil microflora of fodder lands, Journal of Food and Animal Sciences, 01 (01): 22 - 27.

Copyright: Viba, et al. Open Access. This article is distributed under the terms of the Creative Commons Attribution 4.0 International License (http:// creativecommons.org/licenses/by/4.0/), which permits unrestricted use, distribution, and reproduction in any medium, provided you give appropriate credit to the original author(s) and the source, provide a link to the Creative Commons license, and indicate if changes were made. The Creative Commons Public Domain Dedication waiver (http://creativecommons.org/publicdomain/zero/1.0/) applies to the data made available in this article, unless otherwise stated.
} 


\section{Introduction}

Global warming and climate change are the current emerging issues in todays world. Climate is defined as the general or average weather condition of particular regions and it includes the temperature, rainfall and wind in a region. Climate change directly or indirectly affect terrestrial microbial community which includes bacteria, actinomyces, fungi, protozoa etc and their metabolic function, as well as the soil microbes. Soil microbial communities play an important role in agrosystem functioning and are on the field scale, essential for plant growth. Soil organic matter decomposition and control of its cycle, regulation of mineral nutrient availability and production of biologically active substances stimulate plant growth. For decades, soil has been subjected to adverse effects of human activities and climate change, which negatively affect soil biological diversity. Soil fertility, which is fundamental in determining the productivity of all farming systems, is most commonly defined in terms of the ability of soil to supply nutrients to crops.

In India, the increasing population on a near stabilized agricultural land, places a heavy burden on the soil resources particularly its nutrient supplying power. Organic farming envisages the comprehensive management approach to improve the soil health, ecosystem of regions and the quality of the produce. A live healthy soil with proper cropping patterns and integrated nutrient management can sustain optimum productivity over the years. A living soil can be maintained by continuous incorporation of crop and weed biomass, use of animal dung, viz., farmyard manure and compost. The influence of livestock on soil fertility and the influence of soil fertility on livestock nutrition and health are important management factors in organic farming systems. In view of the above observations, this research work was pioneered to study the effects of cow-dung based fertilizers on the culturable resident bacteria in the soil. The effect of organic cow-dung based fertilizers namely cow-dung, aerobic compost and vermicompost on the microbial population of the soil with respect to Bacillus, Pseudomonas and Azetobacter spp. were observed in this study.

\section{Materials and methods}

\section{Experimental sites and design}

Soil from Fodder lands of University livestock farm and fodder research development scheme, Mannuthy was identified for the study. The experimental field selected for the purpose of the study, was divided into 20 equal plots of one square meter in area. Total area of field was $4 \mathrm{mx} 5 \mathrm{~m}$. Among 20 equal plots, three plots each were selected for treatment with three different fertilizers. The field was thoroughly ploughed before adding fertilizer.

\section{Application of fertilizers}

Three organic fertilizers selected for this study were fresh cow-dung, aerobic compost, and Vermicompost. The quantitiy of fertilizer selected for application to the field was cow dung $-1 \mathrm{~kg}$, aerobic compost - 200g and vermicompost - 200g. Individual fertilizer was mixed with water and added to individual small plots. Fertilizers and soil were mixed to form homogeneous mixture. From each treatment plots soil samples were collected for analysis.

\section{Soil sampling}

Soil samples from $0-30 \mathrm{~cm}$ depth were collected randomly and aseptically before and after the addition of fertilizer to the soil. Sampling was done on $0^{\text {th }}$ day, $10^{\text {th }}$ day and $21^{\text {st }}$ day after the treatment of soil with organic cow dung based fertilizer. A control and three replica of each treatment were collected to determine the Total Viable count (TVC) as well as counts of Bacillus, Pseudomonas, and Azotobacter. Results were analysed using ANOVA and the means of bacterial counts were compared with Least significant test (LSD).

Approximately $100 \mathrm{~g}$ of each soil sample was transferred to appropriately labelled sterilized polyethylene bags and transported to the laboratory for analysis.

\section{Processing of Soil Samples}

The soil samples were sieved in order to reduce coarse matter. After sieving, in order to estimate microbial load, $10 \mathrm{~g}$ of the soil sample was transferred into $90 \mathrm{ml}$ of $0.85 \%$ sterile normal saline solution (NSS) so as to form one in 10 dilution. Further, 10 fold serial dilutions were made by transferring one $\mathrm{ml}$ of inoculum into $9 \mathrm{ml}$ of diluent(NSS). Dilutions were made up to $10^{-10}$ and selected dilutions were used for the estimation of microbial loads per gram of samples.

\section{Microbial counts}

Total Viable Count (TVC) of each sample was estimated by pour-plate technique using standard plate count agar (HIMedia). Bacillus, Pseudomonas, Azotobacter Counts was estimated using Bacillus differentiation agar, Pseudomona agar, and Jensons agar (HIMedia) plates respectively. The plates were incubated at $37^{\circ} \mathrm{C}$ for $24 \mathrm{~h}$. Plates with $30-300$ colonies were selected and counts were recorded, and expressed as colony forming unit (CFU)per gram.

The data obtained in the study were subjected to statistical analysis as per procedure described by Snedecor and Cochran (1994), using ANOVA and Least Significance Test. 


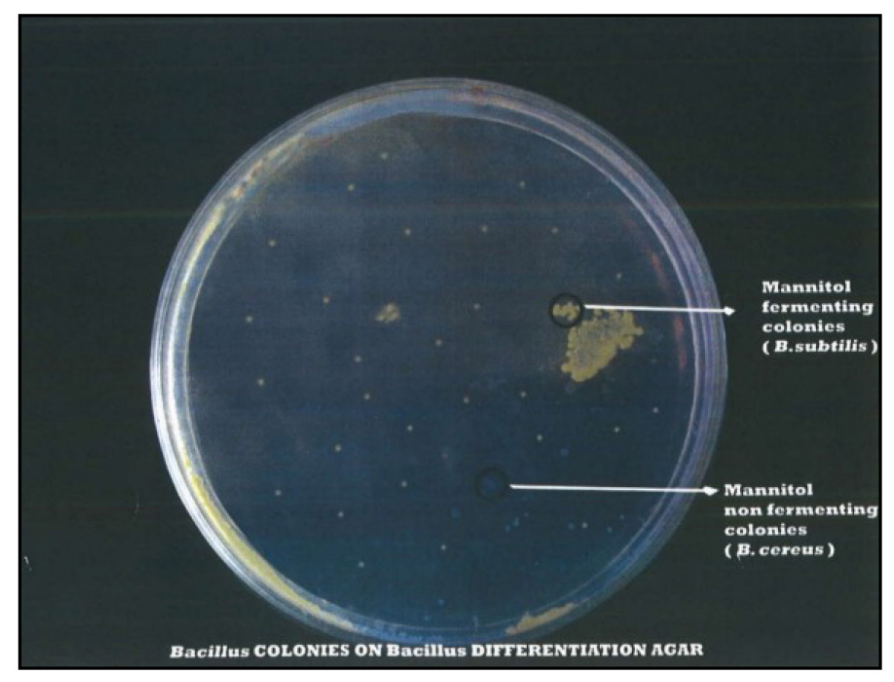

Fig 1. Colonies on Bacillus differentiation agar

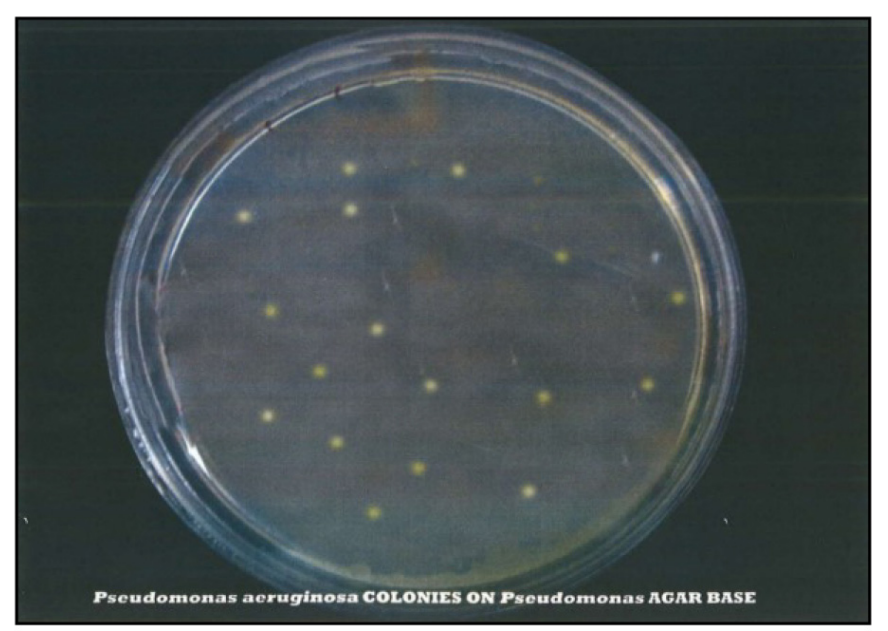

Fig 2. Colonies on Pseudomonas agar

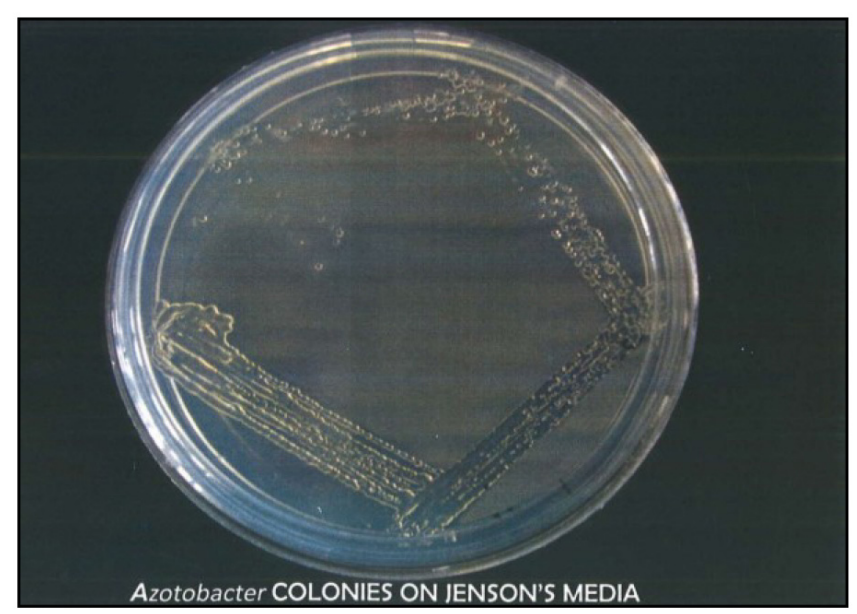

Fig 3. Colonies on Jensons agar

\section{Results and Discussion}

Total Viable Count (TVC) of each sample was estimated by pour-plate technique using standard plate count agar (HIMedia). Bacillus, Pseudomonas, Azotobacter Counts were estimated using Bacillus differentiation agar, Pseudomonas agar, and Jensons agar (HIMedia) plates, respectively, as depicted in Figures 1,2 and 3 . The plates were incubated at $37^{\circ} \mathrm{C}$ for $24 \mathrm{~h}$. Plates with 30-300 colonies were selected and counts were recorded, and expressed as colony forming unit (CFU) per gram.

A graphical representation of different counts in the treated soils are shown below:

Figure 4: Mean counts of treated soil on $0^{\text {th }}, 10^{\text {th }}$ and $21^{\text {st }}$ day of treatment
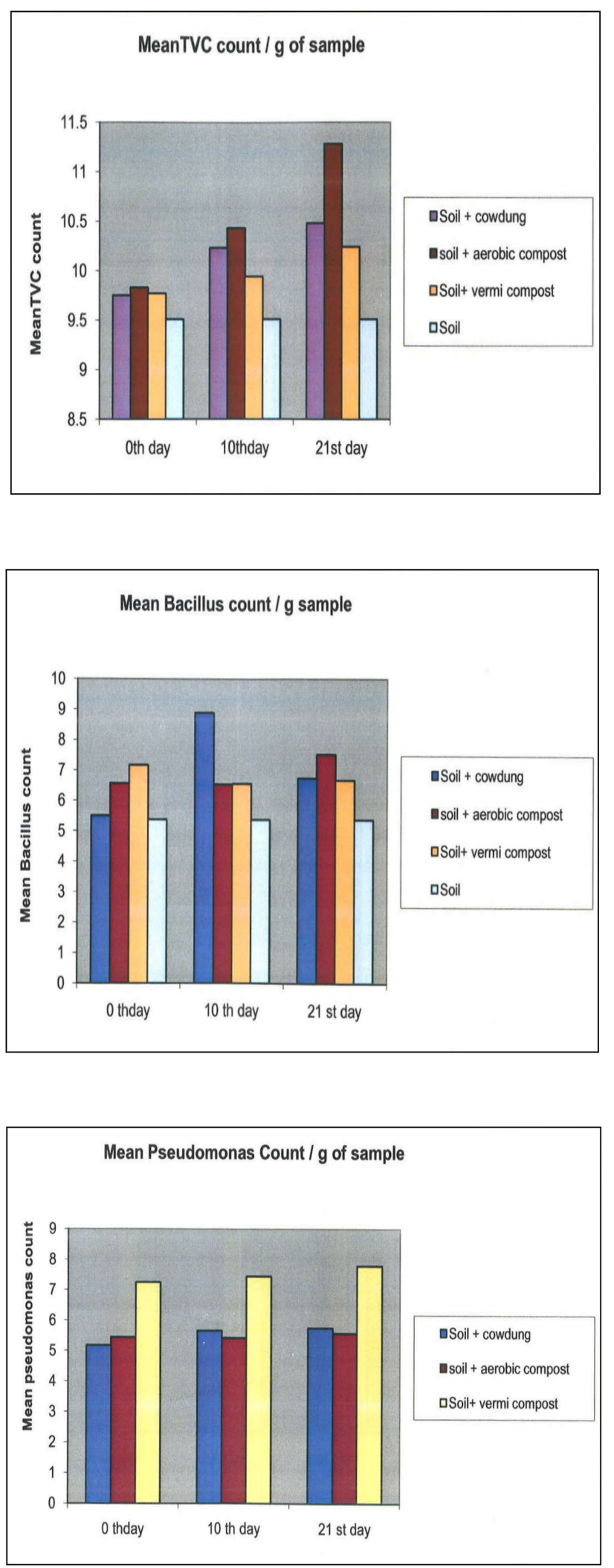


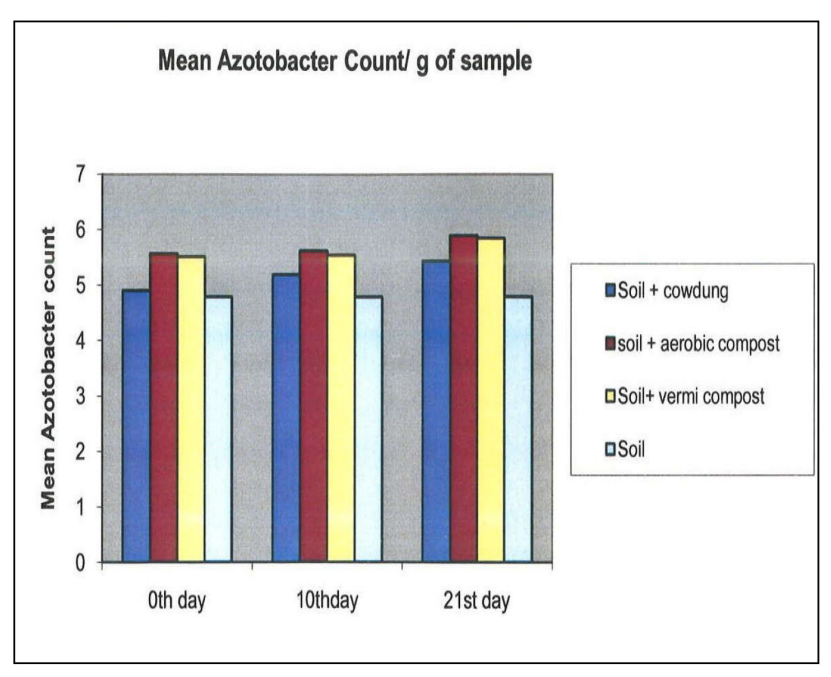

Overall results showed that mean Total Viable Count ranged from $9.72 \pm .04 \log _{10} \mathrm{cfu} / \mathrm{g}$ to $10.38 \pm 0.19$ $\log _{10} \mathrm{cfu} / \mathrm{g}$ and mean Bacillus Count ranged from $6.15 \pm 0.27 \log _{10} \mathrm{cfu} / \mathrm{g}$ to $6.57 \pm 0.86 \log _{10} \mathrm{cfu} / \mathrm{g}$. Mean Pseudomanas Count ranged from $5.95 \pm 0.33 \log _{10} \mathrm{cfu} / \mathrm{g}$ to $6.36 \pm 0.36 \log _{10} \mathrm{cfu} / \mathrm{g}$ and mean Azotobacter Counter ranged from $5.19 \pm 0.13 \log _{10}$ cfu/g to $5.49 \pm 0.15 \log _{10}$ $\mathrm{cfu} / \mathrm{g}$ on $0^{\text {th }}$ and $21^{\text {st }}$ day.

The Aerobic compost treated soil showed higher TVC Count on $21^{\text {st }}$ day while higher Bacillus Count was observed in Cow-dung treated soil on $10^{\text {th }}$ day.

The application of cow-dung based fertilizers showed statistically significant increase in TVC and Pseudomonas counts compared to control soil. These results were in agreement with Nester et al. (1998), who reported that addition of organic material dramatically increased the microbial activity, which plays a crucial part in the breakdown of nutrients so that the plants use them. This was also in accordance with the findings of Albiach et al., (2000) that long-term application of organic fertilizer positively influenced the nutritional quality of the soil and resulted in increased microbial proliferation.

Higher counts were observed on $21^{\text {st }}$ day and lowest count on the $0^{\text {th }}$ day. Of the three fertilizers, the aerobic compost fertilizer increased the Total Viable

Table 1: Mean Total Viable Count and Azotobacter counts in organic fertilizer based soil on $0^{\text {th }}, 10^{\text {th }}$ and $21^{\text {st }}$ day of application

\begin{tabular}{|c|c|c|c|c|c|c|}
\hline \multirow{2}{*}{$\begin{array}{l}\text { Type of organic } \\
\text { fertilizer } \\
\text { enriched }\end{array}$} & \multicolumn{3}{|c|}{$\begin{array}{c}\text { Mean Total Viable Count } \pm \text { SE } \\
\left(\log _{10} \text { CFU/g) }\right.\end{array}$} & \multicolumn{3}{|c|}{$\begin{array}{l}\text { Mean Azotobacter count } \pm \text { SE } \\
\left(\log _{10} \mathrm{CFU} / \mathrm{g}\right)\end{array}$} \\
\hline & $0^{\text {th }}$ day & $10^{\text {th }}$ day & $21^{\text {st }}$ day & $0^{\text {th }}$ day & $10^{\text {th }}$ day & $21^{\text {st }}$ day \\
\hline Control soil & $9.52 \pm 0.03^{b}$ & $9.52 \pm 0.03^{\mathrm{a}}$ & $9.52 \pm 0.03^{\mathrm{a}}$ & $4.79 \pm 0.033^{\mathrm{a}}$ & $4.79 \pm 0.033^{\mathrm{a}}$ & $4.79 \pm 0.033^{\mathrm{a}}$ \\
\hline Cowdung & $9.75 \pm 0.03^{\mathrm{a}}$ & $10.28 \pm 0.03^{\mathrm{a}}$ & $10.48 \pm 0.01^{\mathrm{a}}$ & $4.89 \pm 0.03^{\mathrm{a}}$ & $5.19 \pm 0.08^{\mathrm{a}}$ & $5.43 \pm 0.03^{\mathrm{a}}$ \\
\hline Aerobic compost & $9.84 \pm 0.02^{\mathrm{a}}$ & $10.43 \pm 0.07^{\mathrm{b}}$ & $11.29 \pm 0.06^{\mathrm{b}}$ & $5.56 \pm 0.06^{\mathrm{b}}$ & $5.62 \pm 0.07^{\mathrm{a}}$ & $5.89 \pm 0.03^{\mathrm{a}}$ \\
\hline Vermicompost & $9.78 \pm 0.04^{\mathrm{a}}$ & $9.94 \pm 0.01^{c}$ & $10.24 \pm 0.09^{a}$ & $5.52 \pm 0.05^{c}$ & $5.54 \pm 0.06^{c}$ & $5.84 \pm 0.02^{c}$ \\
\hline Over all mean & $9.72 \pm 0.04$ & $10.04 \pm 0.11$ & $10.38 \pm 0.19$ & $5.19 \pm 0.13$ & $5.28 \pm 0.12$ & $5.49 \pm 0.15$ \\
\hline
\end{tabular}

Figures bearing the same superscript in the same column do not differ significantly. $\left(\mathrm{P} \leq 0.05^{\star} \quad \mathrm{P} \leq 0.01^{\star \star}\right)$

Table 2: Mean Bacillus and Pseudomonas counts in organic fertilizer based soil on $0^{\text {th }}, 10^{\text {th }}$ and $21^{\text {st }}$ day of application

\begin{tabular}{|c|c|c|c|c|c|c|}
\hline \multirow{2}{*}{$\begin{array}{l}\text { Type of organic } \\
\text { fertilizer } \\
\text { enriched }\end{array}$} & \multicolumn{3}{|c|}{$\begin{array}{c}\text { Mean Bacillus count } \pm \text { SE } \\
\left(\log _{10} \text { CFU/g) }\right.\end{array}$} & \multicolumn{3}{|c|}{$\begin{array}{l}\text { Mean Pseudomonas count } \pm \text { SE } \\
\left(\log _{10} \mathrm{CFU} / \mathrm{g}\right)\end{array}$} \\
\hline & $0^{\text {th }}$ day & $10^{\text {th }}$ day & $21^{\text {st }}$ day & $0^{\text {th }}$ day & $10^{\text {th }}$ day & $21^{\text {st }}$ day \\
\hline Control soil & $5.37-0.02$ & $5.37-0.02$ & $5.37-0.02$ & $5.37-0.02$ & $5.37-0.02$ & $5.37-0.02$ \\
\hline Cowdung & $5.50 \pm 0.05^{\mathrm{a}}$ & $5.89=0.03^{\mathrm{a}}$ & $6.74 \pm 0.34^{\mathrm{a}}$ & $5.17 \pm 0.06^{\mathrm{a}}$ & $5.66 \pm 0.04^{\mathrm{a}}$ & $5.74 \pm 0.01^{\mathrm{a}}$ \\
\hline Aerobic compost & $6.56 \pm 0.03^{\mathrm{a}}$ & $6.53-0.08^{b}$ & $7.52 \pm 0.05^{\mathrm{b}}$ & $5.45 \pm 0.06^{\mathrm{b}}$ & $5.42 \pm 0.02^{\mathrm{b}}$ & $5.57 \pm 0.03^{b}$ \\
\hline Vermicompost & $7.17 \pm 0.70^{\mathrm{b}}$ & $6.56-0.03^{\mathrm{c}}$ & $6.67 \pm 0.03^{\mathrm{a}}$ & $7.24 \pm 0.09^{c}$ & $7.44 \pm 0.03^{\mathrm{c}}$ & $7.78 \pm 0.03^{\mathrm{c}}$ \\
\hline Over all mean & $6.15 \pm 0.27$ & $6.08 \pm 0.14$ & $6.57 \pm 0.86$ & $5.95 \pm 0.33$ & $6.15 \pm 0.32$ & $6.36 \pm 0.36$ \\
\hline
\end{tabular}

Figures bearing the same superscript in the same column do not differ significantly. ( $\left.\mathrm{P} \leq 0.05^{\star} \quad \mathrm{P} \leq 0.01^{\star *}\right)$ 
count, Bacillus countand Pseudomonas count compared to the other fertilizers. In the present study, the highest mean Total Viable Count of $11.29 \pm 0.06 \log _{10} \mathrm{CFU} / \mathrm{g}$ was observed in aerobic compost treated soil. This is in accordance with findings of Kim et al., (1997) in which addition of organic matter to soil significantly increased the population of total bacteria compared to control. The highest mean Bacillus count of 7.52 \pm 0.05 $\log _{10} \mathrm{CFU} / \mathrm{g}$ was recorded in aerobic compost. Yoneda and Marva (1975) observed that Bacillus subtilis strain could synthesize extracellular enzymes such as alpha amylase, ribonuclease and protease, which contribute to soil fertility. The highest Pseudomonas count of $7.78 \pm 0.03 \log _{10} \mathrm{CFU} / \mathrm{g}$ was observed in vermicompost treated soil compared to the study of Gynaeshwar et al., (1998). Nnaji et al. (2010) recorded 13\% increase in frequency of Pseudomonas species in treated soil. Highest mean Azetobacter count $\left(5.89 \pm .03 \log _{10} \mathrm{cfu} / \mathrm{g}\right)$ was observed in Aerobic compost treatment. While the lowest mean count $\left(5.43 \pm .03 .03 \log _{10} \mathrm{cfu} / \mathrm{g}\right)$ was observed in Cow-dung treatment when compared to control.

Microbial count analysis on $0^{\text {th }}, 10^{\text {th }}$ and $21^{\text {st }}$ day showed significant increase in microbial population. Thus, cow-dung based fertilizer showed a statistically significant increase in TVC, and Pseudomonas counts compared to control soil. This in turn can lead to better soil health and can aid in enhancing the growth of crops.

\section{Conclusion}

Soil microbes are in many ways affected by the physical and chemical constituents of the soil. Climate and soil quality in various geographical areas influence the survival of these microbes, which definitely will ultimately affect the produce of the land. This study emphasizes the role of organic fertilizers in improving the soil microbial quality. In the present study, while the comparison of the three fertilizers revealed that aerobic compost increased the Total viable and Bacillus counts compared to the other two fertilizers, the highest Pseudomonas count was recorded in Vermicompost treated soil. Organic farming ensures an inherent capacity to maintain and increase overall soil health and fertility, leading to a sustained increase in yield/production of crops. This in turn results in better stability and higher returns in terms of income and sustainability in agriculture.

\section{Authorship contribution statement}

Viba P.G.: Conceptualization, Methodology, Formal analysis, Investigation, Writing - original draft, Writing - review \& editing. Deepa Jolly: Conceptualization, Methodology, Software, Validation, Formal analysis, Investigation, Writing - original draft, Writing review \& editing, Visualization, Supervision, Project administration, Funding acquisition. Latha C.: Conceptualization, Data curation, Writing - original draft, Writing - review \& editing. Vrinda Menon K.: Conceptualization, Methodology, Writing - original draft, Writing - review \& editing. Sethulekshmi C: Conceptualization, Methodology, Writing - original draft, Writing - review \& editing. Joseph Mathew: Conceptualization, Methodology, Writing - original draft, Writing - review \& editing.

\section{Acknowledgments}

All the authors acknowledge and thank to Kerala Veterinary and Animal Sciences University.

\section{Funding}

This compilation is a review article written by its authors and required no substantial funding to be stated.

\section{Declaration of Competing Interest}

All authors declare that there exist no commercial or financial relationships that could, in any way, lead to a potential conflict of interest.

\section{Reference}

Albiach, R., Cancet, R., Pomares, F. And Ingelmo, F. 2000. Microbial biomass content and enzymatic activities after the application of organic amendments to a horticultural soil. Bioresour. Technol. 75: 43-48

Arslan, E.I., Obek, E., Kirbag, S., Ipe, U., and Topal, M. 2008. Determination of the Effect of Compost on Soil Microorganisms. Int. J. Sci. Technol.3: 151 $-159$

Balakrishnan, V., Venkatesan, K. And Ravindran, K. C. 2007. The influence of halophytic compost, farmyard manure and phosphobacteria on soil microflora and enzyme activities. Plant Soil Environ. 53: 186-192

Gunapala, N. And Scow, K. M. 1998. Dynamics of soil microbial bioass and activity in conventional and organic farming systems. Soil Biol. Biochem. 30: 805-816

Gyaneshwar, P., Naresh Kumar, G. And Parekh, L.J. 1998. Effect of buffering on the phosphate solubilising ability of microorganisms world. J. Microbiol. Biotechnol. 14:669-673

Kim, K. D., Nemec, S., and Musson, G. 1997. Effects of composts and soil Amendments on soil Microflora and Phytophthora Root and Crown 
Rot of Bell Pepper, Crop Protection, 16(2) : 165172

Mc Latchey, G. P. and Reddy, K. R 1998: Regulation of organic matter decomposition and nutrient release in a wet land soil. J. Environ. Qual. 27:1268-1274

Mikanova, O., Friedlova, M. And Simon, T. 1996. The influence of fertilization and crop rotation on soil microbial characteristics in the long-term field experiment. Plant Soil Environ,. 55:11-16
Nester. E. W., Pearsall, N. N. And Adreson, D. G. 1998 A Human Perspective. Second edition McGraw Hill Companies, Inc. USA. Microbiol. 722-728

Nanji, N., Adegoke, U.U., Ogbu, H.I., Ezenob, No. O and Okoh, A.I.2010. Effect of long-term organic fertilizer application on soil microbial dynamics. Afr. J. Biotechnol. 10(4): 556-559

Snedecor, .W. and Cochran, W.G. 1994. Statistical methods. Eighth edition. The lowa State University press, Ames, Lowa, U.S.A., pp : 564. 